\title{
Could the ENPP1 p.D85H Mutation be Associated with Hypophosphatemic Rickets?
}

\section{ENPP1 p.D85H Mutasyonu Hipofosfatemik Rikets ile ilişkili Olabilir mi?}

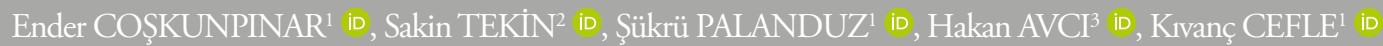 \\ N. Ozan TİRYAKIOĞLU1 ${ }^{1}$ id, Ayșe KUBAT ÜZÜM² id, Refik TANAKOL ${ }^{2}$ id, İlhan SATMAN² id \\ ${ }^{1}$ Department of Internal Medicine, Division of Medical Genetics, İstanbul University İstanbul School of Medicine, İstanbul, Turkey \\ ${ }^{2}$ Department of Internal Medicine, Division of Endocrinology and Metabolism, İstanbul University İstanbul School of Medicine, \\ İstanbul, Turkey \\ ${ }_{3}^{3}$ Department of Otolaryngology, İstanbul University İstanbul School of Medicine, İstanbul, Turkey
}

\section{ABSTRACT}

Objective: A 35-year-old Turkish male patient was referred to us with a year-long history of joint paint and congenital hearing loss. Family history revealed more family members with hearing loss without paraneoplastic syndrome. These findings led us to investigate the genetic alterations associated with familial hypophosphatemia, which revealed an ENPP1 mutation.

Methods: Serum samples were obtained after 12-hour fasting The mutation analysis was performed using previously described primers. Total RNA was isolated from blood samples using Qiagen Total RNA extraction mini kit. cDNA samples were amplified using polymerase chain reaction (PCR), and these PCR products were purified using commercial kits. Following amplification and purification, the PCR products were sequenced.

Results: The patient was found to have hypophosphatemia, a high level of PTH, and elevated plasma alkaline phosphatase. Sequencing results revealed an ENPP1 p.D85H mutation.

Conclusion: We present the identification of an inactivating mutation in the ectonucleotide pyrophosphatase/phosphodiesterase-1. The substituted amino acid residue is highly conserved in ENPP1. At present, we have no further explanation, but our results suggest that ENPP1 p.D85H mutation may be associated with hypophosphatemic rickets accompanied by hearing loss.

Keywords: Hypophosphatemic rickets, hearing loss, ENPP1, mutation

\section{öz}

Amaç: Otuz beş yaşında erkek hasta eklem ağrısı ve doğuştan duyma kaybı şikayetleri ile başvurmuştur. Aile hikayesi paraneoplastik sendrom ile ilişkili olmayan duyma kaybına sahip diğer aile üyeleri olduğunu ortaya çıkarmıştır. Bu bulgular bizi ailesel hipofosfatemi ile ilişkili genetik değişiklikleri incelemeye yönlendirerek bir ENPP1 mutasyonu tespitini sağlamıştır.

Yöntemler: Serum örnekleri 12 saat açlık sonrası toplanmıştır. Mutasyon analizi için daha önce tarif edilen primerler kullanılmıştır. RNA izolasyonu kit ile gerçekleştirilmiştir. cDNA örnekleri PCR ile çoğaltılmış ve PCR ürünleri ticari kitlerle saflaştırılmıştır. Amplifikasyon ve pürifikasyon sonrası ürünler dizilenmiştir.

Bulgular: Hastada hipofosfatemi, yüksek PTH seviyeleri ve artmış alkalin fosfataz seviyeleri belirlenmiştir. Dizileme sonuçları ENPP1 p.D85H mutasyonunu ortaya çıkarmıştır.

Sonuç: Endonükleotid fosfodiesteraz 1 geninde inaktive edici bir mutasyon tanımladık. Değişen amino asit türler arası evrimsel korunum göstermektedir. Şu anda daha fazla açıklama sunamasak da sonuçlarımız ENPP1 p.D85H mutasyonunun duyma kaybı tarafından eşlik edilen hipofosfatemik rikets ile ilişkili olabileceğini göstermektedir.

Anahtar Kelimeler: Hipofosfatemik rikets, duyma kaybı, ENPP1, mutasyon

\section{Introduction}

Serum phosphate levels of less than $2.5 \mathrm{mg} / \mathrm{dL}$ are defined as hypophosphatemia. Phosphate is a crucial component of bone structure. It facilitates adenosine triphosphate (ATP) transport during cell cycle, and its levels in serum affect the enzyme activity (1). Increased phosphate levels are regulated by decreased Vitamin D and increased parathyroid hormone levels. Phosphate regulation is facilitated by parathyroid hormone (PTH) via distal tubules; however, the mechanism remains unknown (2). Recent studies revealed that the gene responsible for the regulation of phosphate levels is located on the $\mathrm{X}$ chromosome, and mutations in this gene result in hypophosphatemic rickets (3). Hypophosphatemia is not associated with race or gender in Caucasians except X-linked hypophosphatemic rickets. Acquired hypophosphatemia is most commonly seen during the transition from puberty to adulthood. With increasing age, it accompanies alcoholism, cancers, malabsorption, and vitamin D deficiency (4). While patients with hypophosphatemia are usually asymptomatic, X-linked hypophosphatemic rickets is characterized by a short stature, bone pain, and

Cite this article as: Coşkunpınar E, Tekin S, Palanduz Ş, Avcı H, Cefle K, Tiryakioğlu NO, et al. Could the ENPP1 p.D85H Mutation be Associated with Hypophosphatemic Rickets? Bezmialem Science 2018; 6: 126-9 
radiological findings (5). In addition, the patients have low 1.25 dihyrodxyvitamin D3 levels. If hypophosphatemia and low 1.25 dihyrodxyvitamine D3 levels are accompanied by high PTH levels, secondary hyperparathyroidism and intestinal malabsorption is suspected (6). Our case had all the mentioned symptoms, in addition to hearing loss. The accompanying hearing loss led us to the genetic investigation as previously described. An early onset conductive hearing loss may further distinguish the ENPP1-related hypophosphatemia from other types of hypophosphatemia (7). A 35-year-old Turkish male patient was referred to us with a year-long history of joint pain and congenital hearing loss. Magnetic resonance imagining (MRI) results were compatible with osteomalacia. Family history revealed other family members with hearing loss. Further investigations showed no signs of paraneoplastic syndrome. The TmP-GFR was also compatible with a phosphate loss in urine. These findings led us to investigate the genetic alterations associated with familial hypophosphatemia, which in turn revealed a ENPP1 mutation.

\section{Methods}

Written informed consent was obtained from all patients, and the study was approved by the Ethical Committee of the Istanbul Faculty of Medicine [2014/792-247]. All measurements were performed on the serum samples obtained after 12-hour fasting, isolated by centrifugation within $30 \mathrm{~min}$ following blood drawing, and stored at $-80^{\circ} \mathrm{C}$ before the biochemical analysis. A mutation analysis was performed using the previously described primers, covering a $569 \mathrm{bp}$ region on ENPP1 cDNA, corresponding to the region between amino acid residues 745 and 941. The total RNA was isolated from blood samples using Qiagen Total RNA extraction mini kit. The isolated RNA samples were converted to cDNA by commercial kits. The cDNA samples were am-

Table 1. Biochemical data of the patients

\begin{tabular}{l|c|c} 
Parameter & Results & Reference Range \\
\hline Creatinine & $0.6 \mathrm{mg} / \mathrm{dL}$ & $0.7-14 \mathrm{mg} / \mathrm{dL}$ \\
\hline Albumin & $4.95 \mathrm{~g} / \mathrm{dL}$ & $3.2-5.5 \mathrm{~g} / \mathrm{dL}$ \\
Sodium & $135 \mathrm{mmol} / \mathrm{dL}$ & $135-146 \mathrm{mmol} / \mathrm{dL}$ \\
\hline Potassium & $4.9 \mathrm{mmol} / \mathrm{dL}$ & $3.5-5.1 \mathrm{mmol} / \mathrm{dL}$ \\
Chloride & $98 \mathrm{mmol} / \mathrm{dL}$ & $95-107 \mathrm{mmol} / \mathrm{dL}$ \\
Phosphorus & $1.9 \mathrm{mg} / \mathrm{dL}$ & $2.7-4.5 \mathrm{mg} / \mathrm{dL}$ \\
\hline Calcium & $9.1 \mathrm{mg} / \mathrm{dL}$ & $8.5-10.5 \mathrm{mg} / \mathrm{dL}$ \\
\hline $25 O H D$ & 38 (ng/ml) & $20-40$ (ng/ml) \\
Alkaline Phosphatase & $246 \mathrm{IUL}$ & $44-147 \mathrm{IU} / \mathrm{L}$ \\
\hline TMP & $80 \%$ & $95 \%-100 \%$ \\
\hline TMP-GFR & $0.62 \mathrm{mmol} / \mathrm{L}$ & $0.96-1.44 \mathrm{mmol} / \mathrm{dL}$ \\
\hline TMP: Tubular Reabsorption of Phosphate; TMP-GFR: Tubular \\
Reabsorption of Phosphate - Glomerular Filtration Rate
\end{tabular}

plified using the PCR, and these PCR products were purified. Following amplification and purification, the PCR products were sequenced.

\section{Statistical analysis}

The detected mutation was compared to the known sequences in various databases. None of the compared sequences included the p.D85H mutation. Since the study involves mutation detection by sequencing, a database comparison statistical analysis was not required.

\section{Results}

All ions and hormones were measured in the serum. The patient was found to have hypophosphatemia, a high level of PTH, an elevated plasma alkaline phosphatase level, normal levels of serum calcium, and vitamin D metabolites $(25 \mathrm{OH}$ and $1.25(\mathrm{OH}) 2)$, consistent with hypophosphatemic rickets (Table 1). Sequencing results revealed a novel mutation (NM_006208.2: c.G1444C, NP_006199.2: p.D85H). The patient was heterozygous for this mutation, while his parents and sibling did not harbor the mutation (Figure 1).

\section{Discussion}

The ENPP1 gene resides in a chromosomal locus that is a suggestive quantitative trait locus for the bone loss in rats (8). We present the identification of an inactivating mutation in the ectonucleotide pyrophosphatase/phosphodiesterase 1 (ENPP1) gene causing autosomal recessive hypophosphatemic rickets (ARHR). Thus, we hypothesized that the ENPP1 activity may play a role in this trait, which will affect the bone loss in turn, as observed in the hypophosphatemic patients. Because the proband is from Turkey, we decided to investigate the previously reported mutations in Turkish patients. The substituted amino acid residue is highly conserved in ENPP1 (Figure 2). Since the 3D structure of the ectonucleotide pyrophosphatase is yet to be revealed, the mutation was not modeled. Instead, we used

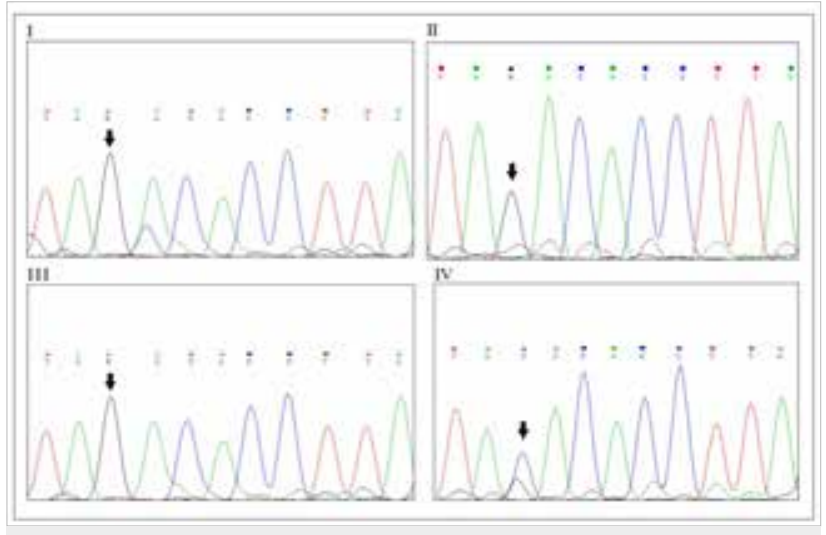

Figure 1 . The father (I), mother (II), and brother (III) are homozygous (G/G) wildtype, whereas the patient (IV) harbors a heterozygous (G/C) c.1444G>C (Asp852His) mutation. Arrows indicate the position of the mutation 

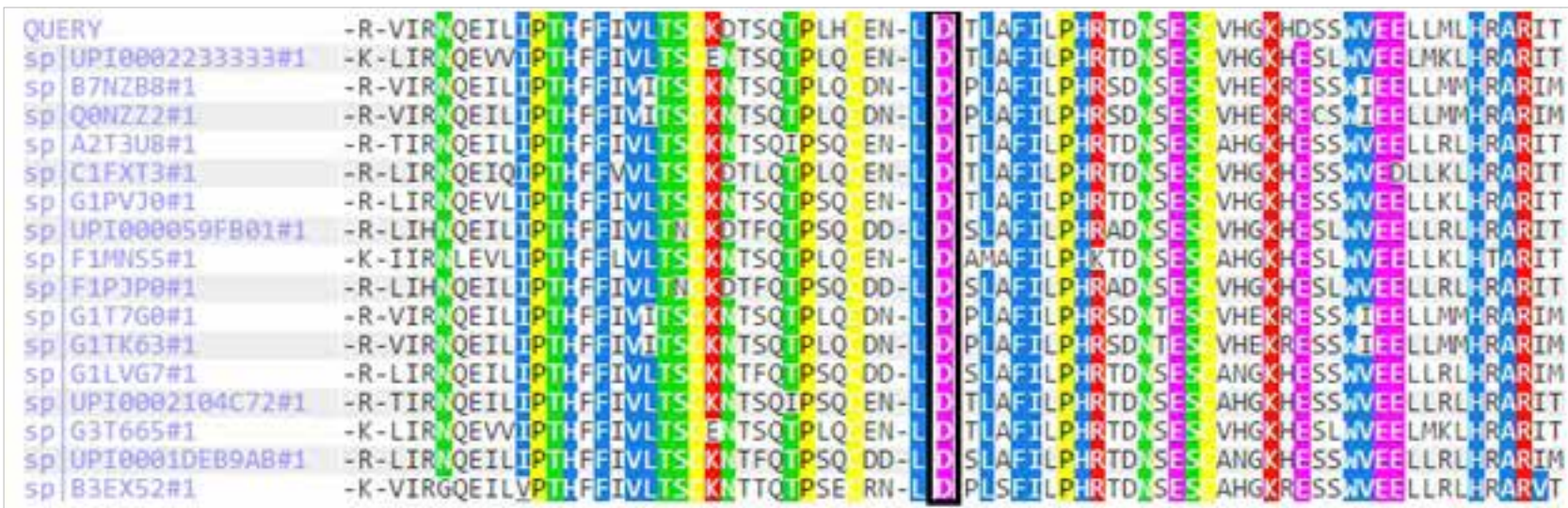

Figure 2 . The ENPP1 protein sequence alignment across different species. The black box indicates the conserved aspartic acid residue

the online mutation effect prediction software, which predicted a highly damaging mutation. The polyphen-2 scoring of mutation effect indicated a highly damaging mutation, where a score closer to 1 indicates a more damaging effect (score: 0.961, sensitivity: 0.78, specificity: 0.95) (9). The Sorting Intolerant from Tolerant (SIFT) scoring of mutation effect also indicated a damaging mutation (SIFT score: 0 ; a score closer to 0 indicates a more damaging effect) (10). At present, we have no further explanation, but our results suggest that the ENPP1 p.D85H mutation may be associated with hypophosphatemic rickets accompanied by hearing loss.

\section{Conclusion}

Our results suggest that the ENPP1 p.D85H mutation may be associated with hypophosphatemic rickets accompanied by hearing loss.

Ethics Committee Approval: Ethics committee approval was received for this study from the ethics committee of the İstanbul University İstanbul School of Medicine (2014/792-247).

Informed Consent: Written informed consent was obtained from volunteers who participated in this study.

Peer-review: Externally peer-reviewed.

Author Contributions: Concept - E.C., S.T., Ş.P.; Design - E.C., K.C., N.O.T.; Supervision - İ.S., Ş.P., Ş.Ö.; Resources - Ş.P., E.C.; Materials - E.C., H.A., S.T., A.K.Ü., R.T.; Data Collection and/ or Processing - E.C., N.O.T., K.C.; Analysis and/or Interpretation - Ş.P., E.C., İ.S., A.K.Ü., R.T.; Literature Search - N.O.T., H.A.; Writing Manuscript - E.C.; Critical Review - E.C., H.A., S.T., Ş.Ö., K.C., A.K.Ü., R.T.

Conflict of Interest: No conflict of interest was declared by the authors.

Financial Disclosure: The authors declared that this study has received no financial support.
Etik Komite Onayı: Bu çalışma için etik komite onayı İstanbul Üniversitesi İstanbul Tıp Fakültesi Klinik Araştırmalar Etik Kurulu'ndan (2014/792-247) alınmıştır.

Hasta Onamı: Yazılı hasta onamı bu çalışmaya katılan gönüllülerden alınmıştır.

Hakem Değerlendirmesi: Dış bağımsız.

Yazar Katkıları: Fikir - E.C., S.T., Ş.P.; Tasarım - E.C., K.C., N.O.T.; Denetleme - İ.S., Ş.P., Ş.Ö.; Kaynaklar - Ş.P., E.C.; Malzemeler - E.C., H.A., S.T., A.K.Ü., R.T.; Veri Toplanması ve/veya İşlemesi - E.C., N.O.T., K.C.; Analiz ve/veya Yorum - Ş.P., E.C., İ.S., A.K.Ü., R.T.; Literatür Taraması - N.O.T., H.A.; Yazıyı Yazan E.C.; Eleştirel İnceleme - E.C., H.A., S.T., Ş.Ö., K.C., A.K.Ü., R.T.

Çıkar Çatışması: Yazarlar çıkar çatışması bildirmemişlerdir.

Finansal Destek: Yazarlar bu çalışma için finansal destek almadıklarını beyan etmişlerdir.

\section{References}

1. Hruska KA. and Lederer, ED. Hyperphosphatemia and hypophosphatemia. Primer on the metabolic bone diseases and disorders of mineral metabolism. 6th. 2006

2. Ambuhl PM, Meier D, Wolf B, Dydak U, Boesiger P, Binswanger U. Metabolic aspects of phosphate replacement therapy for hypophosphatemia after renal transplantation: impact on muscular phosphate content, mineral metabolism, and acid/base homeostasis. Am J Kidney Dis 1999; 34: 875-83. [CrossRef]

3. Drezner MK. PHEX gene and hypophosphatemia. Kidney Int 2000; 57: 9-18. [CrossRef]

4. Kagansky N, Levy S, Koren-Morag N. Hypophosphataemia in old patients is associated with the refeeding syndrome and reduced survival. J Intern Med 2005; 257: 461-8. [CrossRef]

5. Santos F, Fuente R, Mejia N, Mantecon L, Gil-Peña H, Ordoñez FA. Hypophosphatemia and growth. Pediatr Nephrol 2013; 28: 595-603. [CrossRef]

6. Hicks W, Hardy G. Phosphate supplementation for hypophosphataemia and parenteral nutrition. Curr Opin Clin Nutr Metab Care 2001; 4: 227-33. [CrossRef]

7. Steichen-Gersdorf E, Lorenz-Depiereux B, Strom TM, Shaw NJ. Early onset hearing loss in autosomal recessive hypophospha- 
temic rickets caused by loss of function mutation in ENPP1. J Pediatr Endocrinol Metab 2015; 28: 967-70. [CrossRef]

8. Levy-Litan V, Hershkovitz E, Avizov L, Leventhal N, Bercovich D, Chalifa-Caspi V, et al. Autosomal-recessive hypophosphatemic rickets is associated with an inactivation mutation in the ENPP1 gene. Am J Hum Genet 2010; 86: 273-8. [CrossRef]
9. Adzhubei IA, Schmidt S, Peshkin L, Ramensky VE, Gerasimova A, Bork P, et al. A method and server for predicting damaging missense mutations. Nat Methods 2010; 7: 248-9. [CrossRef]

10. Kumar P, Henikoff S, Ng PC. Predicting the effects of coding non-synonymous variants on protein function using the SIFT algorithm. Nat Protoc 2009; 4: 1073-81.[CrossRef] 